\title{
Physicists research practices: A perspective to rethink inquiry-based science education
}

\author{
Suzane El Hage* \\ EA 4692 Centre d'Etudes et de Recherches sur les Emplois et les Professionnalisations (Cérep), Université de Reims \\ (URCA), France \\ *Corresponding Address: suzane.elhage@univ-reims.fr
}

\begin{tabular}{|c|c|}
\hline Article Info & ABSTRACT \\
\hline Article history: & Inquiry-Based Science Education (IBSE) is presented as derived from a \\
\hline Received: May4 $4^{\text {th }}, 2021$ & scientific approach where students are invited to work in the way scientists \\
\hline Accepted: September6 $6^{\text {th }}, 2021$ & work. Studying the proximity between IBSE and scientific approach can be \\
\hline Published: October $30^{\text {th }}, 2021$ & $\begin{array}{l}\text { done through different perspectives; the focus here is on the scientific } \\
\text { approach. The goal of this case study consists in exploring the ways in }\end{array}$ \\
\hline Keywords: & $\begin{array}{l}\text { which scientists perform their research by interviewing } 8 \text { French physicists } \\
\text { volunteers to participate in the study. This preliminary research is the first }\end{array}$ \\
\hline $\begin{array}{l}\text { Physicist; } \\
\text { research practices; } \\
\text { conceptions' modeling; } \\
\text { inquiry-based approach; } \\
\text { science. }\end{array}$ & $\begin{array}{l}\text { step to analyze the contemporary physicists' through research practices, } \\
\text { and then to enrich and question IBSE in a different way. The interviews are } \\
\text { analyzed in terms of moments, specifically a moment called "to explore/to } \\
\text { experiment" with the cke(conception, knowing, concept)framework } \\
\text { allowing to model the conceptions of researchers. The results only show two } \\
\text { common operators }(\mathrm{R}) \text { related to the moment "to explore/ to experiment" } \\
\text { concerning the research processes of the } 8 \text { physicists. However, zero control } \\
\text { structures }\left(\sum\right) \text { are common to any of them. }\end{array}$ \\
\hline
\end{tabular}

(C) 2021 Physics Education Department, UIN Raden Intan Lampung, Indonesia.

\section{INTRODUCTION}

At the international level, the inquirybased approach in science and mathematics didactics has appeared under different names: IBE (Inquiry-Based Education), IBSME (Inquiry-Based Science and Mathematics Education), IBST (InquiryBased Science Teaching). Numerous research studies have taken up IBE from different perspectives (didactic, cognitive, epistemological, etc.). There are many denominations for the inquiry-based approach which is introduced as an approach concerning the way natural science must be taught in school. Several objectives are pursued, let's quote among others: to give students a taste for science, to attract more students to scientific careers, to give a rich description and image of the functioning of science (Ajchenbaum-
Boffety et al., 2000; Eurydice, 2007; Marshall et al., 2017; OECD, 2019; Rocard et al., 2007).

In France, the context is specific: the IBSE (Inquiry-Based Science Education) does not mean exactly the same as in the English-spoken countries (Angelo et al., 2012; Coquidé et al., 2009): "In French institutional texts, the inquiry-based approach is more focused on the experimental approach on the one hand and on the use of the problem-situation with the development of a hypothetical-deductive approach on the other hand. There is a more restrictive conception of the inquiry-based approach recommended in France as compared to what is practiced elsewhere in the Atlantic, or what is published in international reports (our translation)" (Coquidé et al., 2009). 
Some French researchers in science education are led to question the history and epistemology of science in order to characterize the research processes leading to a production of knowledge by inductive, deductive, hypothetico-deductive processes (Bächtold et al., 2012; Cariou, 2011; Hagège, 2016). Another French educational and didactical research have brought results concerning IBE in several dimensions: classification of the inquiry processes (Morge \& Boilevin, 2007), understanding the implementation procedures of the inquiry processes in the classroom (Boilevin, 2013; Calmettes, 2012; Cross \& Grangeat, 2014; Grangeat, 2016; Jameau \& Boilevin, 2015; Rached et al., 2020), characterization of the historical and epistemological features of the inquiry processes (Cariou, 2011), and the comparative analysis and management of inquiry in physics classrooms (Boilevin, 2018).

The research literature covering IBSE is rich. However, few research studies in didactics deal with the analysis of the "contemporary" research approaches in science. This fact leads us to wonder about the epistemological authenticity of InquiryBased Science Education (IBSE) and the relationship between the scientific processes that are being taught and the scientific approach that is used in research. For our purpose, we are following the definition of inquiry-based education as a way of teaching in which learners are invited to work in ways similar to how scientists work.

In the French institutional context, we emphasize the explicit desire to bring together, in both science and mathematics, the appropriation of common skills in relation to the Inquiry-Based Education. It seems to us that the close relationship between two epistemologically different disciplines could produce some difficulties in the implementation of an inquiry-based pedagogy.
Understanding the relation maintained between research practices and IBSE can be questioned at 5 dimensions Boilevin (2013):

- What scientists do: the research practices;

- What is said in the curricula;

- What teachers do especially what tasks are they proposing to their pupils;

- What pupils do: what pupils learn, how they learn;

- What is being evaluated.

In our society, science is in perpetual evolution. We consider that taking into account the dynamic of contemporary scientific practices, especially research approaches, enables us to convey a picture corresponding to what is actually done. This postulate is shared by (Hervé et al., 2021) who are interested in the possible didactic transposition of authentic and contemporary science practices in the agroecology field.

In this paper, we are mainly focusing on the first dimension: "what scientists do: the research practices". Our goal consists in exploring how actual scientists of the $21 \mathrm{st}$ century do research. We position this research in the continuity of the research initiated by Hage \& Ouvrier-Buffet (2018) which contributed to the effort in developing IBSME.

IBSE studies focus on what happens in the classroom regarding either the students or the teacher. In this paper, we are introducing an original methodology to understand contemporary physicists through research practices used at an epistemological level. In other words, this research allows us to explore in which way physicists from different fields, perform their research during different moments and whether there is any convergence between physicians' research practices. The results of the research presented here, allow us to wonder, in a 2 nd step, if it's possible to implement research processes in the classrooms in the field of IBE and to bridge communities of physics researchers and students. 


\section{A focus on scientists' practices}

In science education, the understanding of scientists' research approaches is mainly based on the analysis of articles and books written by researchers and/or epistemologists. In mathematical education where we find some studies concerning contemporary scientific practices (Carlson \& Bloom, 2005; Misfeldt \& Johansen, 2015) conducted mainly by interviews with researchers and not based only on the analysis of articles and books written by researchers like in science. The use of epistemological researches by the didacticians in physics are diverse, some of them exploring the theoretical foundations of constructivism and socio-constructivism which underlie the conception of IBSE (Bächtold et al., 2012). For example, Cariou (2011) offers an interesting historical study focused on a specific moment (hypotheses) of the research activity, and Fabre (2009) deals with the definition and the construction of a problem (the problematization process). Those research studies in science underline the interest of dealing with historical, epistemological and contemporary epistemological approaches for didactic. Hage \& Ouvrier-Buffet (2018) show the need to adopt a new epistemological posture in didactics to enrich the teaching of scientific approaches in science and mathematics education. That is why they interrogate the research processes used by contemporary researchers in Physics and Mathematics in a comparative perspective for IBSME.

\section{Our epistemological point of view}

It is common-sense to assume that there is a gap between the science that is performed by researchers and the teaching of science (Driver et al., 1994). Several researchers in France have tried to minimize the differences between scientific research processes and science teaching processes (IBE) by defining some epistemological criteria (Albe \& Orange, 2011; Maurines \& Beaufils, 2013) and are interested in the image of science conveyed in class (Maurines, 2013). At the international level, some researches have been developed concerning the image of science and its nature because what the teacher knows influences what he or she teaches or does in the classrooms (Abd-El-Khalick, 2013; Adams, 2007; Duschl, Richard \& Grandy, 2013; Lederman \& Lederman, 2019). All the above-mentioned research on scientists practices open new gates for education, investigating deeply scientific processes. That is this contemporary epistemology which underlies our current research. Our research requires a choice of an operational theoretical framework to model the processes of physicist researchers when they do their research. The processes should also allow the analysis of learners' processes during problem solving and inquiry backgrounds. That is why we use Vergnaud schemes and Balacheff ck $\phi$.

The modeling framework $\mathrm{cK} \phi$ (conception, knowing, concept) based on Vergnaud is a way to model the learner's ways of knowing. It is used in mathematics education to model researchers' processes such as defining processes. The ck $\phi$ framework was also mobilized to model the conceptions of three physicists (El Hage \& Plé, 2016) and some physicists \& mathematic researchers (Hage \& OuvrierBuffet, 2018). It is the idea that ckc has the potentiality to model the conceptions of researchers from different fields. That is why we would like to retain this theoretical background.

Let us first explain Vergnaud schemes then the $\mathrm{cK} \phi$ model. Vergnaud (1996) defines a scheme as "the invariant organization of behavior (action) for a certain class of situations". His definition of scheme takes into account four categories of components:

- one or several goals;

- rules to generate action;

- information seeking and control;

- operational invariants (mainly conceptsin-action and theorems-in-action); 
- possibilities of inferences (which enable the subject to infer how to act as time goes by).

What really matters in the determination of those schemes are the operational invariants which characterize the action of subjects, and this is a key point for our modeling of the processes of researchers. Different kinds of operational invariants exist which are explicit or more often implicit and even unconscious. Following these features of schemes, Vergnaud (1996) defines a concept through a triplet, in a psychological and didactical perspective:

- the set of problems which gives meaning to the concept;

- the set of the schemes (i.e., 'known' or 'unknown' strategies) to be implemented by the subjects engaged in such problems;

- the linguistic and non-linguistic forms allowing the symbolic representation of the concept and of the schemes.

Dealing with Vergnaud's (1996) definitions of concept and scheme, and revisiting them, Balacheff (2014) introduces "cK $\phi$ ", a model for "conception", a word often used in science education to refer to theory-in-action (the epistemological status of "conception" is not really different from the one of "misconception"). Balacheff (2014) defines a conception with a quadruplet (the vocabulary is different to avoid confusion with the vocabulary of psychology) (P, R, L, $\Sigma$ ) in which:

- $\mathrm{P}$ is a set of problems;

- $\mathrm{R}$ is a set of operators (operators are tools for action, they can allow the transformation of the problem $\mathrm{P}$;

- L is a representation system (it allows the explanation of operators and controls);

- $\quad \sum$ is a control structure (it ensures the non-contradictory nature of the conception
The control structure includes metacognitive behaviors which are often implicit, such as making choices, taking decisions, judging the advancement of a problem-solving process, expressing judgements etc. The fourth element of the quadruplet is close to Vergnaud's reference to theorems-in-action and inferences. To summarize, this theoretical framework means to distinguish between two kinds of operational invariants in a problem-solving background (in a wide sense): operators i.e. actions of a subject to solve a problem, and control structures i.e. all the means needed by a subject to control their action. Sometimes, there is a permeability between the operator and the control structure (what is an operator during one moment can become a control structure during another moment of the solving process) we will analyze this phenomenon below.

To close this section and to answer our research question, we choose to use the $\mathrm{cK} \phi$ framework with a focus on the operational invariants: then we have to characterize the operators at work along with the control processes. The characterization of the operators models the action of the researchers. Besides, the interest of control structures is that they allow the observer to describe how the subject judges the adequacy and validity of an action (operator), as well as the criteria of the milieu when selecting feedback. However, we will not be focusing on problems and representation systems in order to give an overall image of the research processes. To do that, we need to identify big "moments" of the scientific activity allowing us to use the $\mathrm{Ck} \varnothing$ model without describing P.

\section{Different moments of the scientific research activity}

The choice of these moments should be compatible with science from an epistemological point of view and should not be in contradiction with curricula and future didactical uses. Duschl \& Grandy (2008) define a classical view of the 
traditional scientific practices, following five moments: make observations, formulate a hypothesis, deduce consequences from the hypothesis, make observations to test the consequences, accept or reject the hypothesis based on the observations. The question of "writing about theories" is also pointed out by Duschl \& Grandy (2008), because it depends on the writer and on the audience (and then on the subject's state of knowledge) and it requires a social judgment. We can emphasize as well that the fundamental moment of "problem posing" is not mentioned in the previous five moments while it was explicit in the publication of Ouvrier-buffet et al. (2016) in their research crossing mathematics, physics and biology, they define the nine following moments : (1) exploration of the situation and construction of the problem; (2) formulation of hypothesis/conjectures; (3) test of hypothesis; (4) modeling for example, changing the model, the frame, or the scale; (5) analysis, interpretation of the results \& conclusion; (6) communication of the results and of their impact; (7) generalization of the results, the processes at stake, and the reuse of the process; (8) statement of new problems for the discipline; (9) bibliographical research. This classification works with a characterization of the aims of the nine moments (the aims are specific to a discipline) and with a definition of the problems. It allows the tracking of the evolution and of the transformations of the starting problems during a research process.

Taking into account, on the one hand, the previous researches (and reorganizing it) and on the other hand the last European projects (S-TEAM) dealing with IBE and IBSME, we choose to describe a scientific activity (physics, chemistry etc.) through six "moments of work". The 6 moments match the French science curricula at the first and secondary levels (school, middle school \& high school). That's why we choose to describe research physicists' practices during six moments of a research process which are: (1) to define a problem, (2) to interpret/to analyze a problem (3) to explore/to experiment (4) to formalize, (5) to theorize and (6) to publish/to disseminate. These moments do not describe a linear activity, but they are connected. They give a dynamic overall view of the research process in a mathematical or scientific research.

\section{METHODS}

We have solicited 3 laboratories in France for our case study. We selected and contacted 20 physicists profils among them 8 accepted to be interviewed. Therefore, our qualitative data are composed of 8 audio recorded interviews carried out with the 8 volunteers (see table 1). We will call them P1, P2, P3 etc. they are all involved in teaching activity and research activity.

Table 1. The profiles of the 8 physicist university researchers- teachers.

\begin{tabular}{lcl}
\hline Researcher & $\begin{array}{c}\text { Research } \\
\text { experiene }\end{array}$ & \multicolumn{1}{c}{ Research domain } \\
\hline P1 (Male) & 11 years & Nuclear physics \\
P2 (Male) & 19 years & Nuclear physics \\
P3 (Female) & 19 years & Nuclear physics \\
P4 (Male) & 25 years & Electronic microscopy \\
P5 (Male) & 12 years & Quantum cascade laser \\
P6 (Male) & 33 years & Theoretical physics \\
P7 (Male) & 09 years & Alternative energy \\
P8 (Male) & 25 years & Theoretical physics \\
\hline
\end{tabular}

As we can see that 6 of them are working in the experimental physics field and the other two are in the field of theoretical physics. The interview was structured into two parts: one on their research processes (problems, the hypotheses, the proof, the experiment, modeling processes, the different kinds of writing in research processes, the exchange and cooperation between colleagues) and the other on teaching (the lessons teach by researchers at university level). All the interviews were recorded and conducted in French, scheduled for 1 hour and lasted between 5580 minutes (see figure 1). 


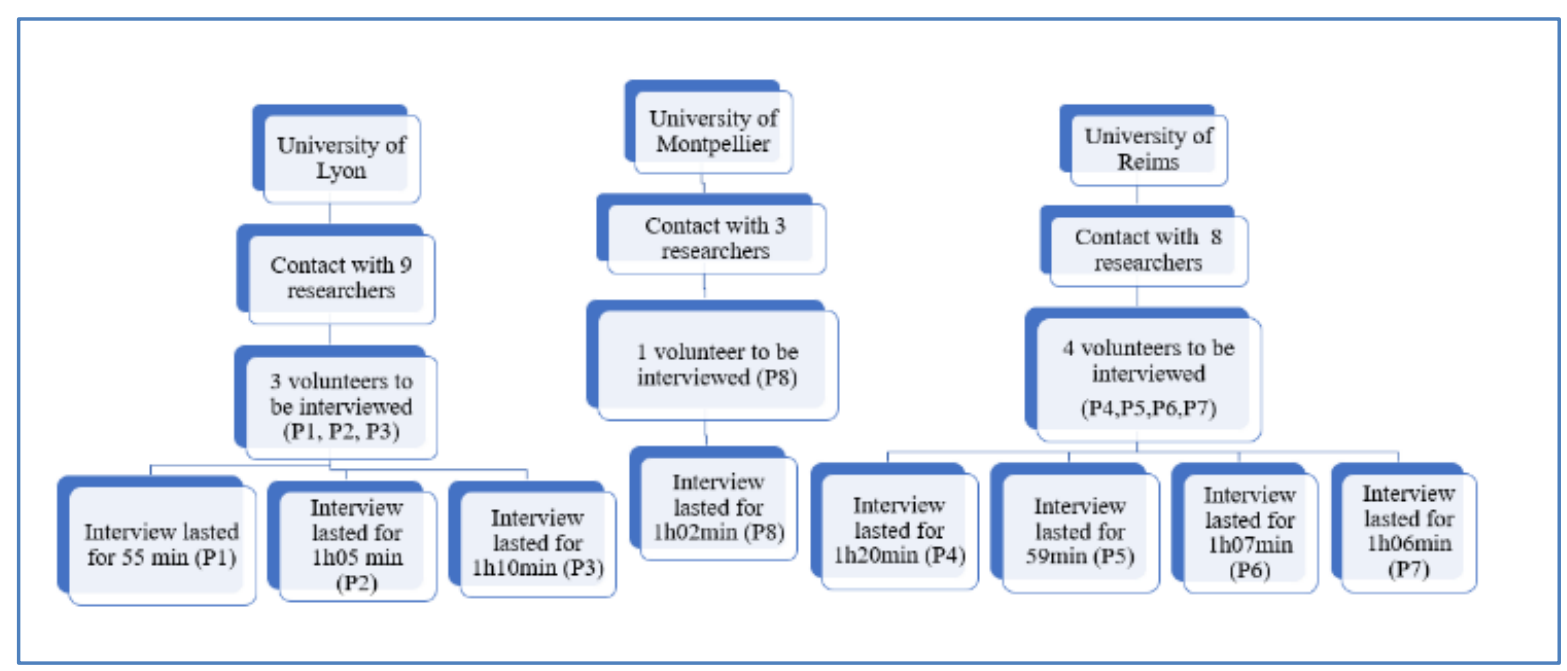

Figure 1. Flow-chart of the collected data

\section{Data coding: encoding interviews with the cke framework}

We built a qualitive methodology that allows us to analyze the way in which each physicist do their research and to find the similarities between the physicists from different fields. All the interviews were transcribed and analyzed in two steps.

Firstly, the transcripts of the interviews were coded according to the theoretical framework following the ck $\varnothing$ model in order to identify the convergences and the divergences in the answers given during the interview between the physicians. Three researchers in didactics made encodings in order to reach a consensus and to select a precise synthetic name or sentence for each operator and each control structure. This name should be a faithful summary of the words of the researchers. Doing that, we got a list of $\mathrm{P}, \mathrm{R}, \mathrm{\sum}$ et $\mathrm{L}$ of each physicists.

Here is an extract of P6 to illustrate how we proceed to encode the data. What is in brackets corresponds to our coding of the researcher's speech using the ckc model.

P6 said: « to explain how proteins are distributing in human cells [P] (...) we choose a model [R1], by model we mean hypothesis. So, we propose a model. Then, we do the calculations [R2]. Based on our chosen model, we expect results [R3]. Once we did that, we went back to see the biologist [R4] saying: « this is the standard model (...) and we are offering a different one, do you know of an experience that would enable to distinguish between the two? [R et $\mathrm{S}] »(. .$.$) So, we're going to$ propose that, therefore this is going to eventually suggest that we or the biologists make new manipulations to test this aspect rather. $[R]$.

Secondly, we grouped the results of the first step according to the six chosen moments (Table 2). The idea was to identify what the convergences were and whether the convergences were located at the same moment of the physicsists' scientific research activity or not.

Table 3. Table of comparison of the operators \& control structures mobilized in physicians' research processes.

\begin{tabular}{|c|c|c|}
\hline \multirow{2}{*}{$\begin{array}{c}\text { Moments of } \\
\text { work }\end{array}$} & \multicolumn{2}{|c|}{ Physics researchers } \\
\hline & P1 & P8 \\
\hline To define a & $\mathrm{R}$ & $\mathrm{R}$ \\
\hline problem & $\sum$ & $\sum$ \\
\hline \multirow[t]{2}{*}{ To interpret } & $\mathrm{R}$ & $\mathrm{R}$ \\
\hline & $\sum$ & $\sum$ \\
\hline To explore/ to & $\mathrm{R}$ & $\mathrm{R}$ \\
\hline experiment & $\sum$ & $\sum$ \\
\hline \multirow[t]{2}{*}{ To formalize } & $\mathrm{R}$ & $\mathrm{R}$ \\
\hline & $\sum$ & $\sum$ \\
\hline \multirow{2}{*}{ To theorize } & $\mathrm{R}$ & $\mathrm{R}$ \\
\hline & $\sum$ & $\sum$ \\
\hline To publish/to & $\mathrm{R}$ & $\mathrm{R}$ \\
\hline disseminate & $\sum$ & $\sum$ \\
\hline
\end{tabular}


In this paper, we will focus on only one moment "to explore/to experiment". This moment is mentioned explicitly in the French science curricula at the primary school and recommended in the ones of physics and chemistry programs at the secondary school level. This moment could start with a proposition of a hypothesis. To be validated or not, the hypothesis must be tested. For this, multiple inquiry modalities could be mobilized, from the implementation of an empirical experiment to a mathematical or numerical modeling. Indeed, we remind that we cannot restrict the physics inquiry to performed experiments; physicians also mobilize another kind of inquiry such as dynamic modeling software, computer simulation etc.

That is why we consider that this moment gathers three moments which are: "Formulate a hypothesis/conjecture", "Test of hypothesis" and "Modeling" (Hage \& Ouvrier-Buffet, 2018). This regrouping allows us to carry out our comparative study based on operators and control structures of the moment "to explore/to experiment".

\section{RESULTS AND DISCUSSION}

In the case of $\mathbf{P 1}$, we identified 10 operators $(\mathrm{R})$ on the total of 6 moments. 3 operators/10 appear on the $\mathrm{M}$ E/E which are: "inventing a process/approach"; "conducting first analysis for prior experiments" and "defining the result validity for a given domain". Concerning control structure $\left(\sum\right)$, it appears $4 \sum$ among them 2 are specific to the moment to explore/to experiment: "checking the conformity of results to theoretical predictive paradigms" and "comparing results with known results in connected field".

In the case of P2, we determined 10 operators $(\mathrm{R})$ in his research activity. 3 $\mathrm{R} / 10$ are part of the $\mathrm{M} E / \mathrm{E}$ which are: "inventing a process/approach"; "conducting first analysis for prior experiments" and "developing new techniques". Concerning control structure, it appears $4 \sum$ among them there is only one specific to this moment: "carrying out the experiment again and checking the reproducibility of results".

In the case of P3, 11 operators are part of her research activity. 3 operators/11 appear which are: "inventing a process/approach"; "conducting prior tests and conducting first analysis for prior experiments".Concerning $\sum$, it appears 7 among them 3 are specific to the $\mathrm{M} \mathrm{E} / \mathrm{E}$ corresponding to "testing hypothesis"; "carrying out the experiment again and checking the reproducibility of results" and "comparing results with known results to connected fields \& bibliography".

In the case of $\mathbf{P 4}, 17$ operators are subsumed in her research activity. 3 operators/17 are specific to this moment: "inventing a process, an approach"; "looking into the feasibility of an experiment" and "conducting $1^{\text {st }}$ analysis of prior experiments". One $\sum$ is specific for this moment which are "checking the conformity of results to theoretical predictive paradigms".

In the case of $\mathbf{P 5}$, we pointed out 09 operators in his research activity. 3 of them are specific to $\mathrm{M} \mathrm{E} / \mathrm{E}$ : "inventing a process, an approach"; "defining objectives and expected results" and "conducting $1^{\text {st }}$ analysis of prior experiments". The analyze reveals only one $\sum$ which is "checking the conformity of results to theoretical predictive paradigms".

In the case of $\mathbf{P 6}, 11$ operators were identified in the 6 moments of her research activity. 2 operators/11 are specific to this moment which are: "inventing a process/approach" and "conducting first analysis for prior experiments". For P4, $4 \sum$ were evoked among them only one specific to this moment: "carrying out the experiment again and checking the reproducibility of results".

In the case of P7, we distinguished 13 operators for all the moments of her research activity. 4/13 are specific to this moment: "inventing a process, an 
approach"; "looking into the feasibility of an experiment"; "conducting prior tests" and "conducting $1^{\text {st }}$ analysis of prior experiments". There is only one $\sum$ which is following "checking the conformity of results to theoretical predictive paradigms".

In the case of $\mathbf{P 8}, 12$ operators were present in her research activity. 4 operator/12 are specific to this moment corresponding to: "defining objectives and expected results"; "inventing a process/approach"; "conducting first analysis for prior experiments and defining the result validity for a given domain". $4 \sum$ were encoded in the discourse of this researcher among them 2 specifics to this moment: "checking the conformity of results to theoretical predictive paradigms" and "comparing results with known results to connected fields \& bibliography".

We show in table 4 and 5 the grouping of all $\mathrm{R}$ and $\sum$ for the French physicists.

Table 4. Operators of the moment "to explore/to experiment"

\begin{tabular}{lc}
\hline Operators (R) & Reseracher \\
\hline $\begin{array}{l}\text { Inventing a process, an } \\
\text { approach }\end{array}$ & $\mathrm{P} 1, \mathrm{P} 2, \mathrm{P} 3, \mathrm{P} 4, \mathrm{P} 5$, \\
$\begin{array}{l}\text { Looking into the feasibility } \\
\text { of an experiment; }\end{array}$ & $\mathrm{P} 6, \mathrm{P} 7, \mathrm{P} 8$ \\
$\begin{array}{l}\text { Defining objectives and } \\
\text { expected results }\end{array}$ & $\mathrm{P} 4, \mathrm{P} 5, \mathrm{P} 7, \mathrm{P} 8$ \\
$\begin{array}{l}\text { Conducting prior tests } \\
\text { Conducting } \text { 1 }^{\text {st }} \text { analysis of } \\
\text { prior experiments }\end{array}$ & $\mathrm{P} 1, \mathrm{P} 2, \mathrm{P} 3, \mathrm{P} 4, \mathrm{P} 5$, \\
$\begin{array}{l}\text { Defining the result validity } \\
\text { for a given domain }\end{array}$ & $\mathrm{P} 6, \mathrm{P} 7, \mathrm{P} 8$ \\
Developing new techniques & $\mathrm{P} 1, \mathrm{P} 8$ \\
\hline
\end{tabular}

Table 5. control structures of the moment "to explore/to experiment"

\begin{tabular}{lc}
\hline Control structure & Reseracher \\
\hline Testing hypothesis & P3 \\
$\begin{array}{l}\text { Carrying out the experiment } \\
\text { again \& checking the }\end{array}$ & P2, P3, P6 \\
$\begin{array}{l}\text { reproducibility of results } \\
\text { Checking the conformity of } \\
\text { results to theoretical } \\
\text { predictive paradigms }\end{array}$ & P1, P4, P5, P7, P8 \\
$\begin{array}{l}\text { Comparing results with } \\
\text { known results in connected } \\
\text { fields \& bibliography }\end{array}$ & P1, P3, P8 \\
\hline
\end{tabular}

The whole interviews and our analysis show two common operators for the moment to explore/to experiment pointed out in Table 3 above (in bold type): The "inventing an approach" and "comparing results with known results to connected fields \& bibliography. However, we find no control structure $\sum$ are common to all the physicists

To illustrate this convergence, here are some excerpts of the interviews: P2 explains that: "To invent a process according to our skills requires that you invent each time a process which matches our aims... (...) This process depends on our colleagues (...)."

P6 said: "Then, there is an experimental process, we design the experiment because we write a program (calculation) and then we try to extract some properties. I search and search, I try to analyze the results and the outputs, and I conclude with what is interesting for me."

In this specific moment "to explore/to experiment", we find no common control structure. However new control structures appear ("new" in the sense that we do not identify them in the other moments): "doing tests and experiments again"; "comparing to known results (from connected fields) and to bibliography"; "checking the conformity to theoretical and predictive paradigms".

We are aware of the fact that research processes could impact teaching in lower and higher education. Moreover, didactic transposition is necessary in order to make a link between the science which is taught and the science which is built. The didactic transposition is the work of transforming knowledge which comes from science (arisen from the research) in an object to be taught. It could be interesting to study the possibilities of didactic transposition of research practices in middle, high school and higher education. We highlight, as an example, the research of Sabra and El Hage (2019); Hage, (2021) studying the potential implementation and qualifying the relation maintained between research and teaching 
activities of few physicists and mathematics teachers-researchers in France.

\section{CONCLUSION AND SUGGESTION}

We are interested by the epistemological fundaments of inquiry-based education. That is why we begin by exploring the way in which a physicist does research. We have shown that the $\mathrm{cK} \varnothing$ model is a working and structuring tool. Our use of this theoretical framework could potentially enrich the epistemological knowledge regarding researchers' practices and has implied didactical results (for instance, new perspectives for managing IBSE in the classrooms). The analysis of the interviews we have conducted with researchers brought out a wider complexity in the comparison between the 08 volunteers' physicists. The moment "to explore/to experiment" of a research activity emphasize 2 common operators.

In the presented research, we analyzed qualitative declarative data and we need in our future research to enrich our analysis not only with the observation of researchers when they do their research but also by studying of their writings.

It is useful to conduct more interviews because science includes chemistry, biology and so on. This is the limit of this study. We may have to conduct interviews with more participants from different fields of science to go further.We also think that it is useful to not limit ourselves to qualitative data especially that the conceptual framework used in this exploratory study shows its solidity that why it the its interest for more quantitative research.

\section{REFERENCES}

Abd-El-Khalick, F. (2013). Teaching with and about nature of science, and science teacher knowledge domains. Science and Education, 22(9), 20872107. https://doi.org/10.1007/s11191012-9520-2

Adams, S. W. (2007). The relationship between understanding of the nature of science and practice: The influence of teachers' beliefs about education, teaching and learning. International Journal of Science, 28(8), 919-944. https://doi.org/10.1080/0950069050049 8351

Ajchenbaum-Boffety, B., Chevalérias, F., Chomat, A., Desbeaux-Salviat, B., Ernst, S., Jasmin, D., Larcher, C., Renoux, Y., Saltiel, E., \&Sarmant, J-P. (2000). La main à la pâte et plan de rénovation de l'enseignement des sciences et de la technologie à l'école, Guide de découverte. INRP.

Albe, V., \& Orange, C. (2011). Sciences des scientifiques et sciences scolaires. Recherches En Didactiques Des Sciences et Des Technologies, 2, 1926. https://doi.org/10.4000/rdst.270

Angelo, M. D., Coquidé, M., \& Magneron, N. (2012). Statut de l'investigation dans des standards del'enseignement scientifique: Cas des USA, de la Suisse etde la France. In B. Calmettes (Ed.), Didactique des sciences et démarches d'investigation:

Références représentations, pratiques et formations. L'Harmattan.

Bächtold, M., De, L., \& De, L. (2012). Les fondements constructivistes de l'enseignement des sciences basé sur l'investigation. Tréma , 38, 1-25.

Balacheff, N. (2014). cK $\varnothing$, a model to reason on learners' conceptions. Conference: Psychology of Mathematics Education, North American Chapter, November 2013.

Boilevin, J.-M. (2018). La démarche d'investigation: Simple effet de mode ou bien nouveau mode d'enseignement des sciences? Epistémologie \& Didactique, December, 195-220. https://doi.org/10.4000/books.pufc. 114 22

Boilevin, J. M. (2013). La place des démarches d'investigation dans l'enseignement des sciences. In $M$. Grangeat (Ed.), Les enseignants de sciences face aux démarches 
d'investigation. Des formations et des pratiques de classe. PUG.

Calmettes, B. (2012). Didactique des sciences et démarches d'investigation. Références, représentations, pratiques et formation. L'Harmattan.

Cariou, J.-Y. (2011). Histoire des démarches en sciences et épistémologie scolaire. RDST - Recherches En Didactique Des Sciences et Des Technologies, 3, 83106. https://doi.org/10.4000/rdst.386

Carlson, P. M. P., \& Bloom, I. (2005). The cyclic nature of problem solving: An emergent multidimensional problemsolving framework. Educational Studies in Mathematics, 58(1), 45-75. https://doi.org/10.1007/s10649-0050808-X

Coquidé, M., Fortin, C., \& Rumelhard, G. (2009). L'investigation: Fondements et démarches, intérêts et limites. Aster, 49 , 51-77. https://doi.org/10.4267/2042/31129

Cross, D., \& Grangeat, M. (2014). Démarches d'investigation: Analyse des relations entre contrat et milieu didactiques. RDST - Recherches En Didactique Des Sciences et Des Technologies, 10, 169-192.

Driver, R., Asoko, H., Leach, J., Mortimer, E., \& Scott, P. (1994). Constructing scientific knowledge in the classroom. Educational Researcher, 23(7), 5-12. https://doi.org/10.1163/2666064406604003

Duschl, Richard A., \& Grandy, R. (2013). Two views about explicitly teaching nature of science. Science and Education, 22(9), 2109-2139. https://doi.org/10.1007/s11191-0129539-4

Duschl, Richard, A., \& Grandy, R. E. (2008). Teaching scientific inquiry: Recommendations for research and implementation. Sense Publishers.

El Hage, S., \& Plé, E. (2016). Démarches d'investigation en sciences: Des références épistémologiques questionnées au regard de la science qui se pratique. $9 e$ Rencontres Scientifiques de l'ARDiST, 388-393.

Eurydice. (2007). Science teaching in schools in europe policies and research. In Education Journal (Issue 106). Commission, European.

Grangeat, M. (2016). Dimensions and modalities of inquiry-based teaching: Understanding the variety of practices. Education Inquiry, 7(4), 421?442. https://doi.org/10.3402/edui.v7.29863

Hage, S. El. (2021). Relation entre l'activité de recherche et d'enseignement des enseignants-chercheurs en physique. Une entrée par l'usage des ressources.in J.-M. Boilevin et A., Jameau (Eds.), Actualité des recherches en didactique des sciences et des technologies. Rencont. ARDiST.

Hage, S. El, \& Ouvrier-Buffet, C. (2018). Les démarches de chercheurs en physique et en mathématiques. Enjeux didactiques d'une nouvelle approche épistémologique. Recherches En Éducation, 34, 1-21. https://doi.org/10.4000/ree.1932

Hagège, H. (2016). La démarche scientifique: invariants et spécificités disciplinaires-une approche épistémologique. IREM de Montpellier.

Hervé, N., Panissal, N., \& Cancian, N. (2021). Quelles références pour enseigner la transition agroécologique? Étude de discours de chercheurs sur leurs pratiques scientifiques. Education \& Didactique, 5(2), 103-123.

Jameau, A., \& Boilevin, J.-M. (2015). Les déterminants de la construction et de la mise en œuvre de démarches d'investigation chez deux enseignants de physique-chimie au collège. Recherches En Éducation, 21, 108120. https://doi.org/10.4000/ree.7545

Lederman, N. G., \& Lederman, J. S. (2019). Teaching and learning nature of scientific knowledge: Is it déjà vu all over again?.Disciplinary and Interdisciplinary Science Education Research, 1(6), 1-9. 
Marshall, J. C., Smart, J. B., \& Alston, D. M. (2017). Inquiry-based instruction: A possible solution to improving student learning of both science concepts and scientific practices. International Journal of Science and Mathematics Education, 15(5), 777-796. https://doi.org/10.1007/s10763-0169718-x

Maurines, L. (2013). Les programmes de sciences du lycée en France et la nature des sciences: Rapport à la vérité, aux croyances et à la culture. In G. Zoïa (Ed). Actualité de La Recherche En Éducation et Formation (AREF) Conference.

Maurines, Laurence, \& Beaufils, D. (2013). Teaching the nature of science in physics courses: The contribution of classroom historical inquiries. Science \& Education, 22(6), 1443-1465. https://doi.org/10.1007/s11191-0129495-z

Misfeldt, M., \& Johansen, M. W. (2015). Research mathematicians' practices in selecting mathematical problems. Educational Studies in Mathematics, 89 , 357-373. https://doi.org/10.1007/s10649-0159605-3

Morge, L., \& Boilevin, J.-M. (2007). Séquences d'investigation en physique - chimie au collège et au lycée. SCEREN, 167.

OECD. (2019). PISA 2018 Results (Volume I): What students know and can do. OECD Publishing. https://doi.org/10.1787/5f07c754-en

Ouvrier-buffet, C., Bosdeveix, R., \& Hosson, C. De. (2016). Inquiry-based education (IBE): Towards an analysing tool to characterise and analyse inquiry processes in mathematics and natural sciences. In In: Hodgson B., Kuzniak A., Lagrange JB. (eds) The didactics of mathematics: Approaches and issues (p. 1910217). Springer, Cham. https://doi.org/10.1007/978-3-31926047-1

Rached, E., Grangeat, M., Rached, E., \& Grangeat, M. (2020). French teachers' informal formative assessment in the context of inquiry-based learning of inquiry-based learning. International Journal of Science Education, 43(3), 385-406.

https://doi.org/10.1080/09500693.2020. 1740818

Rocard, M., Csermely, P., Jorde, D., Lenzen, D., Walberg-Henriksson, H., \& Hemmo, V. (2007). L'enseignement scientifique aujourd'hui: Une pédagogie renouvelée pour l'avenir de l'Europe. Communautés européennes, Direction générale de la recherche Science, économie et société.

Sabra, H., \& El Hage, S. (2019). Relation between teaching and research in mathematics and physics at university: From the lens of interaction with resources. in desingning instruction. In L. Trouche, G. Guedet G., \& B. Pepin (Eds.). Ressources in Teachers' Professional Activity.

Vergnaud, G. (1996). The theory of conceptual fields. In Theories of Mathematical Learning (1st Editio, p. 22). 